\title{
Factors associated with the rural and remote practice of medical workforce in Maluku Islands of Indonesia: a cross-sectional study
}

\author{
Farah Noya ${ }^{1,2,6^{*}} \mathbb{D}$, Sandra Carr ${ }^{1}$, Sandra Thompson ${ }^{3}$, Rhonda Clifford ${ }^{4}$ and Denese Playford ${ }^{5}$
}

\begin{abstract}
Background: Many factors contribute to engagement in rural and remote (RR) medical practice, but little is known about the factors associated with rural and remote medical practice in such remote locations as the Maluku Province of Indonesia. This study describes factors associated with actual RR practice, preferred RR practice, and intention to remain practice in Maluku Province.

Methods: An online survey of work-related experience and intentions for future rural work was administered to 410 doctors working in the Maluku province of Indonesia. Participant characteristics were described using descriptive statistics, associations between the independent variables with the location of the workforce, intention to remain practice in Maluku, preference for future RR practice in Maluku were analysed using Chi-square tests and logistic regression.
\end{abstract}

Results: A total of 324 responses (79\% response rate) were recorded, comprising 70\% females and 30\% Pattimura University graduates of doctors employed in Maluku. Doctors working in RR areas were more likely to be a GP (OR 3.49, $\mathrm{Cl}$ 1.03-11.8), have a monthly salary of more than IDR 6 million (OR 11.5, Cl 4.24-31.1), and have no additional practice (OR 2.78, $\mathrm{Cl} 1.34-5.78)$. Doctors intended to stay practice in Maluku were more likely to be born in Maluku (OR 7.77, Cl 3.42-17.7) and have graduated from Pattimura University (OR 3.06, Cl 1.09-8.54), and less likely to be a temporary employee (OR 0.24, $\mathrm{Cl} 0.10-0.57)$. Doctors who prefer future RR practice in Maluku were more likely to experience rural living (OR $2.05 \mathrm{Cl}$ 1.05-3.99), have a positive indication of the impact of community exposure during medical schools on their current practice (OR 2.08, Cl 1.06-4.09), currently practising in RR Maluku (OR 8.23, Cl 3.27-20.8); and less likely to have bigger take-home pay (OR 0.30, Cl 0.13-0.70).

Conclusion: This study indicates that special attention should be given to recruiting doctors with a rural background and ongoing support through attractive opportunities to build a sustainable RR workforce. Since a regional medical school helps supply doctors to the RR areas in its region, a sustained collaboration between medical schools and local government implementing relevant strategies are needed to widen participation and improve the recruitment and retention of RR doctors.

Keywords: Archipelagic context, Developing country, Medical workforce, Rural background, Regional medical school, Recruitment and retention of rural doctors, Rural and remote practice, Rural intention, Rural preference

\footnotetext{
*Correspondence: farah.noya@research.uwa.edu.au

${ }^{6}$ Health Professions Education Building, The University of Western

Australia, Crawley Avenue (off Mounts Bay Road-next to CAR PARK 25), Nedlands, WA 6009, Australia

Full list of author information is available at the end of the article
}

\section{Background}

A shortage of health personnel and workforce maldistribution means unequal access to healthcare for people living in rural and remote (RR) communities, a persistent 
and significant problem globally [1-3]. Indonesia, a middle-income country in the Asian region, struggles with community access to healthcare and insufficient health workforce, especially in its RR areas [4-6]. Indonesia has $29 \%$ of its districts categorised as underdeveloped and has almost three-fourth of its areas classified as rural [7]. Having ratio of doctors per population 1:2294 nationally, its health data shows maternal mortality rate 177/100,000 live births [8], higher than the World Health Organisation (WHO) target in the context of the Sustainable Development Goals (SDGs) [9], and neonatal mortality rate 15 deaths/1000 live births [8], higher than the SDGs target 12/1000 live births [10]. Despite these poor outcomes, the national government allocates just $5 \%$ of its budget for health [11]. Service coverage index of Universal Health Coverage (UHC) through Indonesian National Health Insurance was $60 \%$ in 2020, with higher UHC achieved mostly in Java Island and some western parts of Indonesia [12].

Maluku, a province in the eastern Indonesian archipelago, includes some of the most remote, isolated and poorly served islands $[8,13,14]$. According to the Ministry of Health of the Republic of Indonesia, the characteristic of the working area of a health service facility is classified into urban, rural, remote and very remote areas. Maluku health service facilities were determined remote, very remote, and unattractive [15], underdeveloped (73\% of the province districts) [13], and in the outermost islands (17\% of national numbers) [14] include challenging conditions. They are: located in areas that are difficult to reach or prone to disasters; small islands, island clusters, or coastal regions; have poor routine public transportation access (once per week); long travel times to the district/city capital (more than $6 \mathrm{~h}$ round trip); travel may be hindered by the climate or weather; experience difficulties in fulfilling essential commodities; and may have unstable security conditions [15].

In addition to the remote and isolated nature of the province being a disincentive for medical personnel choosing to live and work there $[4,16,17]$, the region has less infrastructure, facilities and amenities, difficulties with communication, perceived lower quality of children's education and lower employment income [4, $16,17]$. In Indonesia, the national health data analysis shows that the number of doctors in an area was positively related to population numbers, population density, number of hospitals and community health centres [17]. The ratio of doctors per population is 1:7269 in Maluku. In recent years, the central government has implemented various policies such as compulsory work placements and financial and career incentives to attract and bond doctors and health professionals to remote and isolated areas of Indonesia through Temporary Assignment and Nusantara Sehat schemes [4, 16, 18]. Even though Maluku has been one province, where doctors may extend their stay after compulsory work placements with government incentives [19], the small numbers of doctors in RR areas of Maluku remains a significant issue [8].

Subsequently, Maluku has national data showing maternal mortality rates (>177/100,000 live births), infant mortality rates ( $>22$ deaths/1000 live births) and infectious diseases rates that are many times higher than in countries with acceptable access to care $[8,20]$. In this province, the service coverage index of UHC was only $55 \%[12]$.

Maldistribution of rural health personnel, particularly doctors, occurs globally [2, 21-23]. Recruitment and retention of doctors in rural areas is influenced by many factors, including personal characteristics such as rural background and educational elements including rural exposure during medical training. A scoping review of 61 papers published between 2010 and 2020 [24] concluded that rural background and rural training are decisive factors in recruiting and retaining doctors in $R R$ areas [25-49].

In Indonesia, before establishing Pattimura University Medical School in Ambon, Maluku, doctors who worked in Maluku predominantly graduated from medical schools in Java Island (Jakarta, Surabaya, Yogyakarta, and Bandung) and cities outside Java Island, such as Medan, Makassar and Manado. In 2008, an undergraduate medical school was established in Pattimura University to educate medical students to work locally in Maluku. The government partly funded the first five cohorts of 50 students to encourage graduates to serve the province, with more than $20 \%$ of students having a rural background [50]. The vision was to improve the number of doctors (an additional 50) in Maluku by 2015.

Understanding factors associated with the medical workforce taking up RR practice in Indonesia, specifically Maluku, is limited and not adequately addressed in Indonesian and international research. Hence, this study aimed to investigate factors related to doctors' preferences to work in the RR areas of Maluku Province. Specifically, this research answers three research questions:

1. What are the characteristics of doctors who work in Maluku?

2. Which demographic variables are associated with current RR location of practice, intention to remain to practise in Maluku, and RR practice preference in Maluku?

Besides being relevant as an evaluation of the current program in Pattimura University, findings from this study can inform policy and practice for other archipelago 
regions and other low- and middle-income countries, especially within the Asian region with similar societal and regional geographical characteristics.

\section{Methods}

\section{Study population}

The study population comprised qualified doctors who were currently working in Maluku Province.

\section{Inclusion and exclusion}

Doctors employed in Maluku (hospitals and health clinics, administrators and academics), of any age, gender and discipline/specialty area were included. Those temporarily unemployed or working in another province were excluded.

\section{Sampling}

Based on the data recap provided by the Health Human Resources division of Maluku Province Health Office, 496 doctors worked in Maluku. However, the given list provided 440 names. After ethical and governance approvals from The University of Western Australia, Pattimura University and the Maluku Province government, all doctors were invited to participate in the study. Their names and contact details were provided by the provincial and regents health offices and the Pattimura University Medical School alumni database.

\section{Recruitment}

After excluding 30 doctors who were on other assignments outside Maluku during the survey period, 410 doctors were identified as working in Maluku, 133 (32\%) males and 277 (68\%) females. All were invited to participate in the study via a text message to the mobile number provided by the health offices and medical school. This message contained information about the study with a link to the online survey. Consent to participate was embedded in the online survey.

\section{Instruments}

The 51-item survey developed by the researchers was informed by the literature (Additional file 1: Survey questionnaire) and included multiple-choice, dichotomous, multi-response and Likert type questions. The sections included:

1. Demographic details, including the rural background (rural born, Maluku born, rural living experience and the length of rural living experience).

2. Medical training history, including rural exposure.

3. Employment status and history, including practice location defined using the Indonesian Centre Bureau of Statistic classification for urban and rural areas in
Maluku [7], with the site of practice converted to the category (rural $=1$ or urban $=0$ ).

4. Outcome variables, i.e., current practice is in $R R$ areas, intended to remain practice in Maluku, and preferred future RR practice in Maluku.

\section{Data collection}

Online-based delivery was the most feasible option given the doctors' geographical distribution. The survey was open for 2 months to mitigate limited internet access in the Maluku area.

\section{Data analysis}

All analyses were undertaken based on valid cases using IBM SPSS statistics version 26. Descriptive statistics were used to determine participants' characteristics. A Shapiro-Wilks test was used to confirm the normality of the data distribution. Chi-square tests were performed after a test of independence between outcome variables and independent variables (Tables 2, 3 and 4) to determine the relationships between both. The outcomes of interest were defined as:

1. The current workplace is in RR Maluku areas $(0=\mathrm{No}$, $1=$ Yes)

2. The intention to remain working in Maluku $(0=$ No, $1=$ Yes).

3. The preferred future location of practice in Maluku is $\mathrm{RR}$ areas $(0=$ No, $1=$ Yes $)$.

A test of multicollinearity was performed using $r$ value for Spearman Correlation. When two variables had significant and positive strong relationship ( $r$ value of more than 0.7 ), selection for further analysis was based on the significance of the variables. Binary logistic regression was based on variables with a significance level $<0.20$ to estimate odds ratios associated with factors determine the target outcomes. A confidence interval of $95 \%$ and alpha significance level of 0.05 were used. A further collinearity diagnostic was perform using variance inflation factor (VIF) in linear regression with all variables in three outcomes of interest showed VIF around 1.

\section{Results}

Characteristic of respondents

There were 324 doctors who recorded responses, so $79 \%$ of eligible participants commenced the survey, with 241 (59\%) completed surveys. Non-completion was reported by some of the respondents mainly due to problems with internet stability. Respondents were more likely to be young (mean 33.4 years), female, married, and Maluku 
Table 1 Characteristics of respondent doctors working in Maluku Province

\begin{tabular}{|c|c|}
\hline & $N^{a}(\%)$ \\
\hline \multicolumn{2}{|l|}{ Medical training history } \\
\hline \multicolumn{2}{|l|}{ Medical school origin } \\
\hline All else & $227(70)$ \\
\hline Pattimura University & $97(30)$ \\
\hline \multicolumn{2}{|c|}{ Community exposure during medical training } \\
\hline No & $9(3)$ \\
\hline Yes & $315(97)$ \\
\hline \multicolumn{2}{|c|}{ Indicated impact of community exposure ${ }^{b}$} \\
\hline Negative & $34(12)$ \\
\hline Passive & $155(54)$ \\
\hline Positive & $98(34)$ \\
\hline \multicolumn{2}{|l|}{ Rural exposure } \\
\hline No & $33(11)$ \\
\hline Yes & $254(89)$ \\
\hline \multicolumn{2}{|l|}{ Demographic variables } \\
\hline \multicolumn{2}{|l|}{ Gender } \\
\hline Male & $76(29)$ \\
\hline Female & $183(71)$ \\
\hline \multicolumn{2}{|c|}{ Age (23-66 years, mean 33.4 STDEV 8.4) } \\
\hline Less than mean & $157(65)$ \\
\hline More than mean & $84(35)$ \\
\hline \multicolumn{2}{|l|}{ Marital status } \\
\hline Married & $133(51)$ \\
\hline Unmarried & $126(49)$ \\
\hline \multicolumn{2}{|l|}{ Have child/ren under care } \\
\hline Yes & $107(41)$ \\
\hline No & $152(59)$ \\
\hline \multicolumn{2}{|l|}{ Rural born } \\
\hline No & $189(76)$ \\
\hline Yes & $60(24)$ \\
\hline \multicolumn{2}{|l|}{ Province of birth is Maluku } \\
\hline No & $89(36)$ \\
\hline Yes & $159(64)$ \\
\hline \multicolumn{2}{|l|}{ Rural living experience } \\
\hline No & $147(59)$ \\
\hline Yes & $102(41)$ \\
\hline \multicolumn{2}{|c|}{ Length of rural living experience } \\
\hline Less than 10 years & $179(72)$ \\
\hline Minimum of 10 years & $69(28)$ \\
\hline \multicolumn{2}{|l|}{ Employment variables } \\
\hline \multicolumn{2}{|l|}{ Employment status } \\
\hline Permanent & $117(44)$ \\
\hline Temporary & $149(56)$ \\
\hline \multicolumn{2}{|l|}{ Specialisation in medicine } \\
\hline General practitioner (GP) & $249(86)$ \\
\hline Medical specialist & $39(14)$ \\
\hline \multicolumn{2}{|c|}{ Length of work since graduation ${ }^{c}$} \\
\hline More than 5 years & $117(41)$ \\
\hline Up to 5 years & $171(59)$ \\
\hline
\end{tabular}

Table 1 (continued)

\begin{tabular}{|c|c|}
\hline & $N^{\mathrm{a}}(\%)$ \\
\hline \multicolumn{2}{|c|}{ Length of work in current practice ${ }^{c}$} \\
\hline More than 5 years & $86(30)$ \\
\hline Up to 5 years & $202(70)$ \\
\hline \multicolumn{2}{|c|}{ Monthly salary (Mean IDR 5,917,765, Stdev 4,575,245) } \\
\hline IDR 6 million and less & $178(67)$ \\
\hline \multicolumn{2}{|l|}{ (IDR 1 million-IDR 29 million) } \\
\hline Greater than IDR 6 million & $88(33)$ \\
\hline \multicolumn{2}{|l|}{ Additional practice } \\
\hline No & $182(68)$ \\
\hline Yes & $84(32)$ \\
\hline \multicolumn{2}{|c|}{ Take-home pay (Mean IDR 11,928,497, Stdev 13,390,630) } \\
\hline IDR 12 million and less & $182(69)$ \\
\hline \multicolumn{2}{|c|}{ (IDR 1.5 million-IDR 150 million) } \\
\hline Greater than IDR 12 million & $83(31)$ \\
\hline \multicolumn{2}{|l|}{ Outcome variables } \\
\hline \multicolumn{2}{|c|}{ Current practice is in rural and remote Maluku areas } \\
\hline No & $118(41)$ \\
\hline Yes & $169(59)$ \\
\hline \multicolumn{2}{|c|}{ Preferred future location of practice ${ }^{e}$} \\
\hline Outside Maluku & $58(23)$ \\
\hline Urban Maluku & $128(52)$ \\
\hline Rural Maluku & $62(25)$ \\
\hline
\end{tabular}

a Not all participants answered every question so the numbers do not add to 324

${ }^{\mathrm{b}}$ Adjusted to dichotomous with a median of $8(0=$ less positive, $1=$ more positive)

' Highly associated with younger age, excluded from the regression model

${ }^{\mathrm{d}}$ Take-home pay here includes medical service fees in Indonesian casebased group (INA-CBGs) and or capitation within Indonesian National Health Insurance, also practice and other service fees

e Adjusted for outcome 2: intended to remain in Maluku for future practice $(0=$ No, $1=$ Yes $)$; adjusted for outcome 3 : those who prefer rural and remote practice in Maluku $(0=\mathrm{No}, 1=$ Yes $)$

born (Table 1). Of the females, $61 \%$ were working in a RR practice location. Of all respondents born in Maluku, less than a third were born in RR areas. More than half the respondents had never lived in rural areas before commencing medical school. Most doctors graduated from medical schools in cities outside Java (Fig. 1), and almost all respondents experienced some rural exposure during their medical program (Table 1).

Most respondents had worked less than 5 years since graduation and under 5 years in their current post, had only temporary contracts, and did not undertake additional practice besides their main job (Table 1). Of the 11 regencies in Maluku, respondents predominantly worked in Ambon (39\%), the capital city of Maluku, and the nearest regency from the capital, Central Maluku regency (21\%) (Fig. 2).

Figure 3 shows that there was no significant difference in salary between durations of work and that take-home 


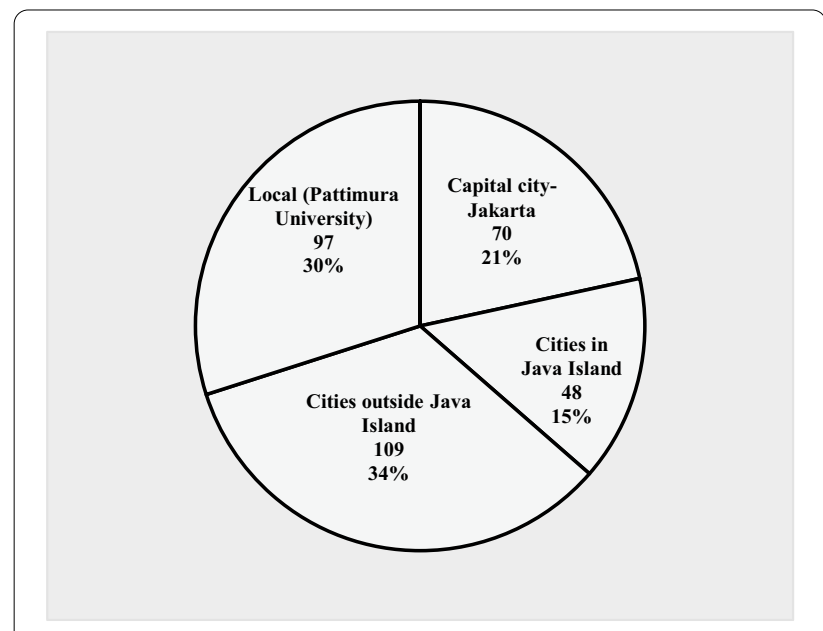

Fig. 1 Location of participants' medical schools

pay was higher for those who had worked for more than 10 years. Cross tabulation of the monthly wage with a specialty in medicine showed that more general practitioners (GP) received a salary of more than 6 million IDR ( $90 \%$ vs $84 \%$ who received $\leq 6$ million IDR). Meanwhile, for take-home pay, more GPs received up to 12 million IDR ( $97 \%$ vs $57 \%$ who received more than 12 million IDR). Take-home pay includes medical service fees in Indonesian case-based groups (INA-CBGs) and or capitation* within Indonesian National Health Insurance as well as practice and other service fees. The analysis of duration of work with monthly take-home pay and location of current work and additional practice showed that of doctors who had worked for more than 10 years, $50 \%$ had an additional practice, and $78 \%$ were located in more developed urban areas, Ambon city (59\%) and Central Maluku Regency (15\%). In addition, those doctors with take-home pay greater than IDR 12 million were mainly of older age (OR 6.41, CI 95\% 3.46-11.9, $p=0.000$ ), permanent employees (OR 4.45, CI 95\% 2.50-7.92, $p=0.000$ ) and specialists (OR 27.5 , CI 95\% 10.1-74.8, $p=0.000$ ) who need specialist facilities so are permitted to have up to an additional two practices [51].

More than half the respondents stated their preferred future location for work was in the urban areas of Maluku, with only a quarter nominating to stay in RR posts in Maluku (Table 1). Four essential specialty areas in Indonesian Medicine (Internal Medicine, Paediatrics, Obstetrics and Gynaecology, Surgery) were the commonly chosen future disciplines, with Internal Medicine the most favoured (36; 14.5\%; Fig. 4).

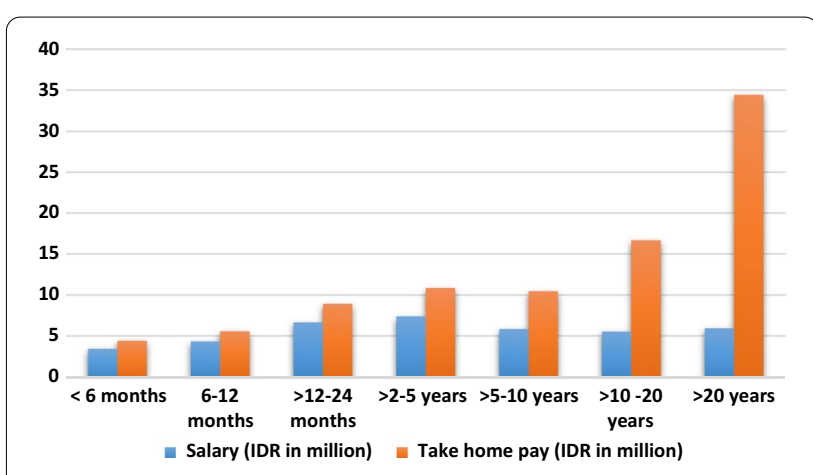

Fig. 3 Average monthly salary and take-home pay over the duration of work

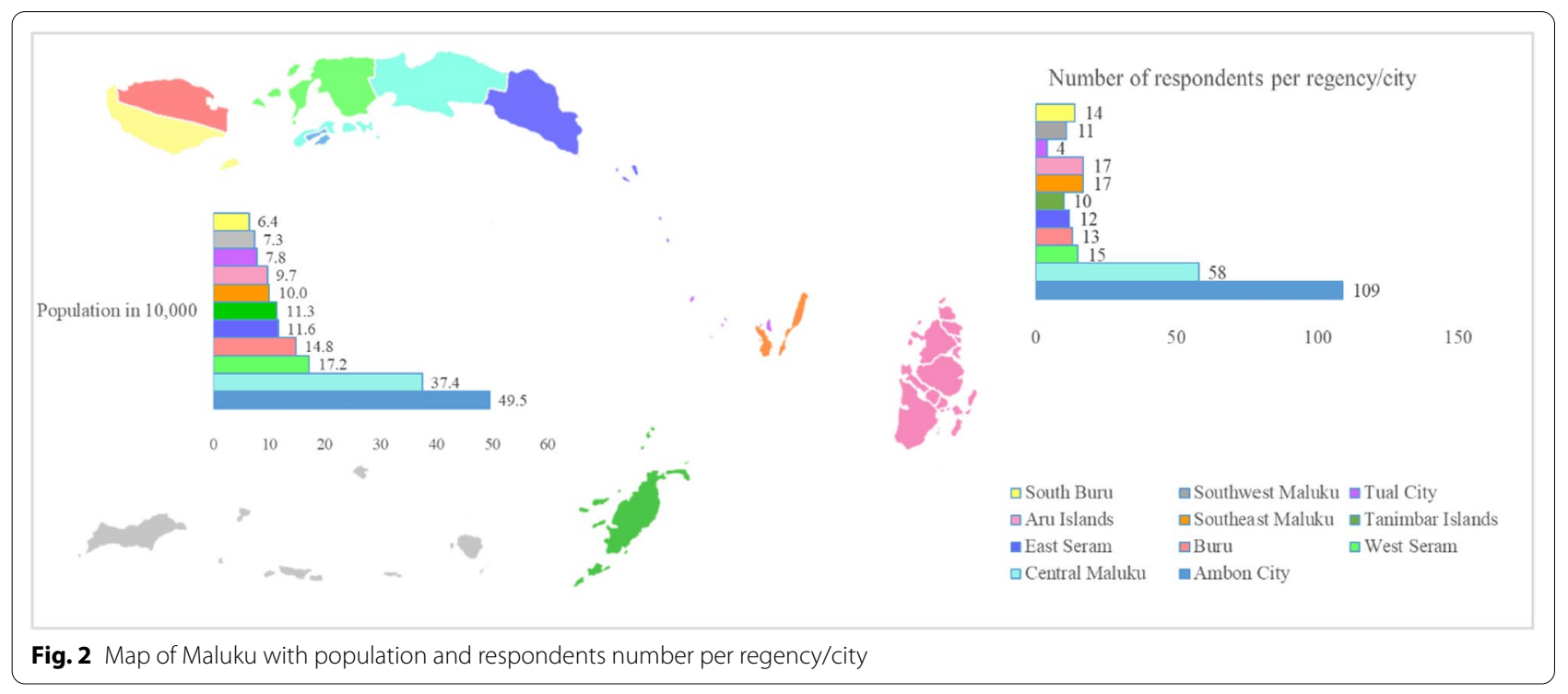




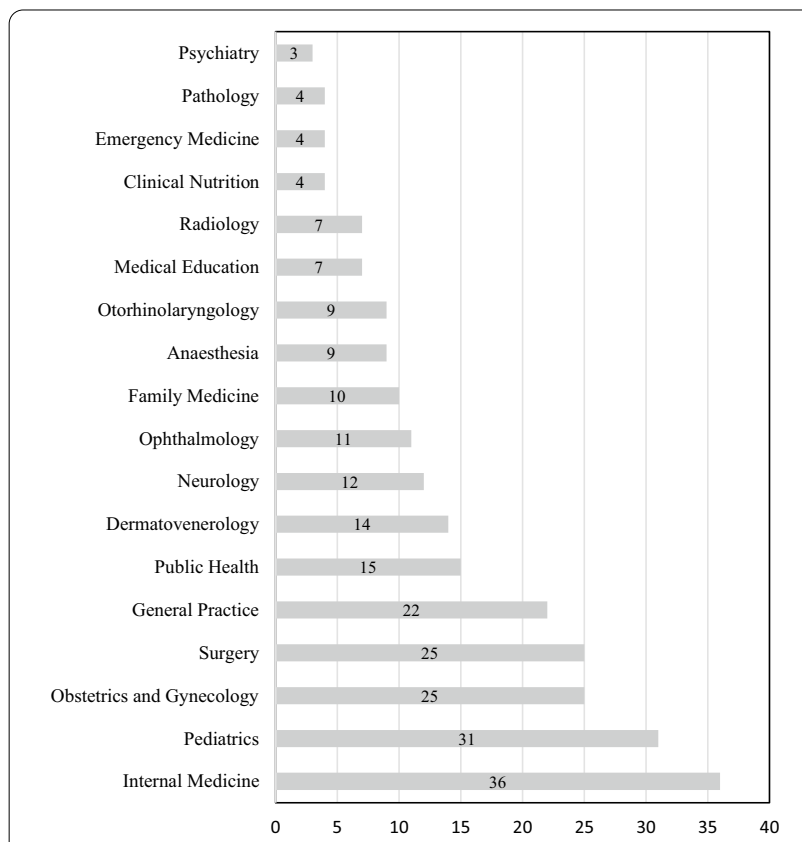

Fig. 4 Participant's future practice type preference

\section{Rural and remote practice in Maluku Province (Table 2)}

Univariate analysis showed strong associations between the current rural practice location with younger age ( $\leq 33$ years), Pattimura graduates, general practitioners, monthly salary more than IDR 6 million, and having no additional practice. These associations were not significant in the multivariate model. There was no association between rural practice location with rural born, Maluku born, and rural exposure. Multivariate logistic regression showed that doctors currently practice in a RR location were more likely to; be a GP (OR 3.49, CI 1.03-11.8), have a monthly salary of more than IDR 6 million (OR 11.5, CI 4.24-31.1), and have no additional practice (OR 2.78, CI 1.34-5.78).

\section{Intention to remain practice in Maluku Province (Table 3)}

Univariate analysis showed three factors positively associated with intention to remain practice in Maluku Province; Maluku born (OR 11.4, CI 5.65-23.1), rural exposure during medical school (OR 2.46, CI 1.10-5.48), and Pattimura University graduates (OR 4.25 CI 1.839.88). With OR less than 1 , being younger doctors (OR 0.41 , CI 0.20-0.85), having temporary employment status (OR 0.33, CI 95\% 1.19-3.98), and having no additional practice (OR 0.27, CI 95\% 0.12-0.60) were negatively associated with intention to stay practice in Maluku. In other words, those who intend to stay were more likely doctors who were older, in permanent employment, and having additional practice. Multivariate analysis revealed that doctors intended to stay practice in Maluku were more likely to be born in Maluku (OR 7.77, CI 3.42-17.7), and have graduated from Pattimura University (OR 3.06, CI 1.09-8.54), and less likely to have temporary employment status (OR 0.24, CI 0.10-0.57).

\section{Rural and remote preference of practice in Maluku Province (Table 4)}

There were positive associations between younger age, rural born, Pattimura graduates experienced multistage, multifocal community exposure during medical school, indicated a positive impact of community learning on current practice, being a GP, practising RR currently, with the preferred location of practice being rural and remote Maluku. Having take-home pay more than 12 million IDR was negatively associated with rural preference among those intended to stay in Maluku. Controlling for confounding variables, doctors who prefer rural practice in Maluku were more likely to have rural living experience (OR 2.05, CI 1.05-3.99), have a positive indication of the impact of community exposure during their medical schools on their current practice (OR 2.08, CI 1.064.09), have current practice in RR Maluku (OR 8.23, CI 3.27-20.8), and less likely to have monthly take-home pay more than IDR 12 million (OR 0.30, CI 0.13-0.70).

\section{Discussion}

This survey of doctors living and practising in the Maluku Province of Indonesia offers valuable insights into factors significant to recruiting and retaining a sustainable rural workforce.

This study identified that doctors currently working in Maluku were predominantly female, of young age, married, did not have a rural background, graduated from a university outside Maluku, and experienced rural exposure. They mainly were working rurally, GPs, held temporary contracts, at early stage career, received salary up to IDR 6 million and take-home pay up to IDR 12 million, and have no additional practice.

Doctors currently working in rural and remote Maluku were more likely to be general practitioners with salaries more than IDR 6 million and no additional practice. Doctors intending to remain in Maluku Province were more likely Maluku born, Pattimura graduates, and permanent workers. Doctors who preferred RR Maluku for their future practice were more likely to have current practice in RR Maluku and rural living experiences and less likely to have take-home pay over IDR 12 million.

This study identified more doctors practising rural were female $(70 \%)$. This finding is notably different from other international $[27,36,52]$ and current Indonesian [53] studies describing characteristics of RR doctors, 
Table 2 Variables associated with the current rural and remote practice location

\begin{tabular}{|c|c|c|c|c|c|c|c|}
\hline & \multirow[t]{2}{*}{$N$ valid cases } & \multicolumn{2}{|c|}{ Location of practice } & \multicolumn{2}{|c|}{ Univariate } & \multicolumn{2}{|c|}{ Multivariate } \\
\hline & & Rural (\%) & Urban (\%) & $p^{*}$ & OR (Cl 95\%) & $p^{*}$ & OR (Cl 95\%) \\
\hline \multicolumn{8}{|l|}{ Demography } \\
\hline Age (less than mean 33.35) & 240 & 73 (mean 32) & 53 (mean 36) & 0.002 & $2.36(1.37-4.08)$ & & \\
\hline Gender (female) & 258 & 70 & 73 & 0.616 & $0.87(0.50-1.51)$ & & \\
\hline Marriage status (single) & 258 & 54 & 39 & 0.022 & $1.81(1.09-3.02)$ & & \\
\hline Have child/ren under care (No) & 258 & 65 & 49 & 0.010 & $1.95(1.17-3.02)$ & & \\
\hline \multicolumn{8}{|l|}{ Rural background } \\
\hline Rural born & 248 & 26 & 21 & 0.317 & $1.37(0.74-2.54)$ & & \\
\hline Province of birth is Maluku & 247 & 63 & 66 & 0.556 & $0.85(0.50-1.46)$ & & \\
\hline Have rural living experience & 248 & 44 & 36 & 0.232 & $1.38(0.81-2.35)$ & & \\
\hline More than 10 years of rural living experience & 100 & 52 & 50 & 0.477 & $1.24(0.69-2.22)$ & & \\
\hline \multicolumn{8}{|l|}{ Medical training and community exposure } \\
\hline Pattimura medical school origin & 287 & 36 & 23 & 0.017 & $1.90(1.12-3.24)$ & & \\
\hline $\begin{array}{l}\text { Multistages of learning using community } \\
\text { exposure }\end{array}$ & 279 & 53 & 43 & 0.112 & $0.47(0.09-2.36)$ & & \\
\hline $\begin{array}{l}\text { Positive impact of community exposure to } \\
\text { medical practice }\end{array}$ & 245 & 43 & 34 & 0.187 & $1.42(0.84-2.41)$ & & \\
\hline Multi foci of community exposure & 279 & 73 & 64 & 0.100 & $1.54(0.92-2.56)$ & & \\
\hline $\begin{array}{l}\text { Experienced rural exposure during medical } \\
\text { training }\end{array}$ & 279 & 90 & 86 & 0.391 & $1.37(0.66-2.85)$ & & \\
\hline \multicolumn{8}{|l|}{ Employment factors } \\
\hline Specialty in medicine (GP) & 287 & 90 & 81 & 0.037 & $2.05(1.04-4.06)$ & 0.044 & $3.49(1.03-11.8)$ \\
\hline Temporary employment status & 265 & 61 & 50 & 0.079 & $1.56(0.95-2.57)$ & & \\
\hline Monthly salary more than IDR 6 million & 265 & 46 & 13 & 0.000 & $5.97(3.09-11.5)$ & 0.000 & $11.5(4.24-31.1)$ \\
\hline Having no additional practice & 265 & 23 & 45 & 0.000 & $2.73(1.60-4.65)$ & 0.006 & $2.78(1.34-5.78)$ \\
\hline $\begin{array}{l}\text { Monthly take home pay more than IDR } 12 \text { mil- } \\
\text { lion }\end{array}$ & 265 & 35 & 24 & 0.046 & $1.76(1.01-3.09)$ & 0.055 & $3.04(0.98-9.44)$ \\
\hline
\end{tabular}

The bold emphasises the significance of the variables and their ORs

${ }^{*}$ The Chi-square statistic is significant at the 0.05 level

where male doctors tend to be the majority. However, another Indonesian study with a similar archipelagic context found that females were dominant $(59 \%)$ in the rural workforce [54]. While not showing association in this sample, another study in Australia has reported that more women are applying to Rural Clinical Schools [40] and proportionately more are going on to rural work [32], thus beginning to redress rural workforce shortages in female practitioners.

The majority of doctors practising in Maluku graduated from medical schools in regional or provincial capitals, including almost a third from Pattimura University, Maluku. Given that most of our respondents were Maluku-born, this finding confirms that regional students come back to their regions [55-57], and implies that significant efforts should be put into developing regional medical schools to improve doctors' distribution to the regions [55-57].

Interestingly, in this study, rural exposure during medical training, one of the most widely reported factors in other studies, was not associated with RR practice location and preference for RR practice location in Maluku. This was also found in a study from Canada [58]. However, the study was from 1999 when medical schools were in the early stages of advancing rural experiences for their students. A current study with early-career Indonesian doctors showed that doctors practising in remote locations were likely to have a clerkship in a remote district [53]. And a 10-year longitudinal cohort study from Australia revealed that rural exposure during medical training related to rural work [59].

While not significantly associated with rural practice location and rural preference in this study, we found that most doctors experienced rural exposure during their medical training, more than what was found in the national study [53]. This is similar to the Australian requirement that all students experience rural work during their medical training [59]. Moreover, we found that rural exposure was associated with more than twofold 
Table 3 Variables associated with intention to stay practice in Maluku Province

\begin{tabular}{|c|c|c|c|c|c|c|c|}
\hline & \multirow[t]{2}{*}{$N$ valid cases } & \multicolumn{2}{|c|}{$\begin{array}{l}\text { Intention to } \\
\text { remain practice } \\
\text { in Maluku } \\
\text { Province } \\
\end{array}$} & \multicolumn{2}{|c|}{ Univariate } & \multicolumn{2}{|c|}{ Multivariate } \\
\hline & & Yes (\%) & No (\%) & $p^{*}$ & OR (Cl 95\%) & $p^{*}$ & OR (Cl 95\%) \\
\hline \multicolumn{8}{|l|}{ Demography } \\
\hline Gender (female) & 248 & 70 & 69 & 0.881 & $1.05(0.56-2.00)$ & & \\
\hline Age (less than mean 33.35) & 231 & 62 & 80 & 0.014 & $0.41(0.20-0.85)$ & & \\
\hline Marriage status (single) & 248 & 48 & 59 & 0.153 & $0.65(0.36-1.18)$ & & \\
\hline Have children under care (No) & 248 & 57 & 74 & 0.018 & $0.46(0.24-0.88)$ & & \\
\hline \multicolumn{8}{|l|}{ Rural background } \\
\hline Rural born & 248 & 26 & 21 & 0.526 & $1.26(0.62-2.58)$ & & \\
\hline Province of birth is Maluku & 247 & 77 & 22 & 0.000 & $11.4(5.65-23.1)$ & 0.000 & $7.77(3.42-17.7)$ \\
\hline Have rural living experience & 248 & 42 & 38 & 0.621 & $1.17(0.64-2.13)$ & & \\
\hline More than 10 years of rural living experience & 248 & 19 & 22 & 0.562 & $0.81(0.40-1.66)$ & & \\
\hline \multicolumn{8}{|l|}{ Medical training and community exposure } \\
\hline Graduated from Pattimura Medical School & 248 & 37 & 12 & 0.000 & $4.25(1.83-9.88)$ & 0.033 & $3.06(1.09-8.54)$ \\
\hline Multistage learning using community exposure & 241 & 51 & 44 & 0.378 & $1.31(0.72-2.38)$ & & \\
\hline $\begin{array}{l}\text { Indicated positive impact of community exposure } \\
\text { to medical practice }\end{array}$ & 241 & 39 & 25 & 0.053 & $1.93(0.99-3.78)$ & & \\
\hline Multifocal community exposure & 241 & 73 & 61 & 0.100 & $1.69(0.90-3.15)$ & & \\
\hline Experienced rural exposure during medical training & 241 & 90 & 79 & 0.024 & $2.46(1.10-5.48)$ & & \\
\hline \multicolumn{8}{|l|}{ Employment factors } \\
\hline General practitioners & 248 & 83 & 91 & 0.124 & $0.47(0.17-1.26)$ & & \\
\hline Temporary employment status & 248 & 51 & 76 & 0.001 & $0.33(0.17-0.65)$ & 0.001 & $0.24(0,10-0.57)$ \\
\hline Monthly salary more than IDR 6 million & 248 & 31 & 33 & 0.807 & $0.92(0.49-1.73)$ & & \\
\hline Having no additional practice & 248 & 63 & 86 & 0.001 & $0.27(0.12-0.60)$ & 0.066 & $0.38(0.17-1.07)$ \\
\hline Monthly take home pay more than IDR 12 million & 248 & 31 & 24 & 0.348 & $1.38(0.70-2.72)$ & & \\
\hline Currently work in rural/remote Maluku & 247 & 62 & 66 & 0.670 & $0.88(0.47-1.62)$ & & \\
\hline
\end{tabular}

The bold emphasises the significance of the variables and their ORs

*The Chi-square statistic is significant at the 0.05 level

rates of intention to remain practice in Maluku. More directed positive strategies are needed.

Another important factor reported elsewhere as a determinant of RR practice uptake is rural background $[25-41,53]$, but it was not associated with rural practice location in this study. However, rural born and rural living experiences were associated with the preference of future rural practice location in Maluku, with rural living experience independently associated (twofold rates) with the preference. We also found that Maluku born, although not meaning rural born, was associated significantly with the intention to stay practice in Maluku Province. All of these factors should inform the development of pro-rural work policies for this archipelago.

These positive policies are not only the domain of Western countries, as we confirm that a geographical maldistribution exists even in this developing province [60]. However, since our findings suggest that being rural born were associated with the intention to remain practice in Maluku, more focus and attention should be given to the recruitment of students and doctors with a rural background. Although this finding is not novel, this study confirms the pattern among the limited number of studies from low- and middle-income countries.

In addition, evidence suggests that widening access to medical courses enhanced care to underserved communities [61-65]. A more comprehensive approach is needed to widen the participation and aspirations for medicine of under-represented socio-economic and educationally disadvantaged groups. This approach could include regent government early education programs and support, including scholarships aimed at these underrepresented groups.

Regarding future practice type preference, doctors in Maluku preferred to work in specialist practices, namely, Internal Medicine, Paediatrics, Obstetrics and Gynaecology, and Surgery. Specialist practice, especially within the four major specialties, is an opportunity to earn more 
Table 4 Variables associated with rural and remote preference among doctors who intended to remain practise in Maluku

\begin{tabular}{|c|c|c|c|c|c|c|c|}
\hline & \multirow[t]{2}{*}{$N$ valid cases } & \multicolumn{2}{|c|}{$\begin{array}{l}\text { Prefer RR Maluku } \\
\text { for future } \\
\text { practice }\end{array}$} & \multicolumn{2}{|c|}{ Univariate } & \multicolumn{2}{|c|}{ Multivariate } \\
\hline & & Yes (\%) & No (\%) & $p$ & OR (Cl 95\%) & $p$ & OR (Cl 95\%) \\
\hline \multicolumn{8}{|l|}{ Demography status } \\
\hline Age (less than mean 33.35) & 231 & 77 & 62 & 0.039 & $2.02(1.03-3.95)$ & & \\
\hline Gender (female) & 248 & 76 & 68 & 0.231 & $1.49(0.77-2.88)$ & & \\
\hline Marriage status (single) & 248 & 57 & 48 & 0.271 & $1.38(0.78-2.47)$ & & \\
\hline Have child/ren under care (No) & 248 & 68 & 59 & 0.202 & $1.48(0.81-2.72)$ & & \\
\hline \multicolumn{8}{|l|}{ Rural background } \\
\hline Rural born & 248 & 34 & 20 & 0.031 & $2.00(1.06-3.77)$ & & \\
\hline Province of birth is Maluku & 247 & 74 & 61 & 0.053 & $1.87(0.99-3.56)$ & & \\
\hline Have rural living experience & 248 & 41 & 36 & 0.009 & $2.16(1.20-3.86)$ & 0.036 & $2.05(1.05-3.99)$ \\
\hline More than 10 years of rural living experience & 248 & 23 & 19 & 0.519 & $1.26(0.63-2.53)$ & & \\
\hline \multicolumn{8}{|l|}{ Medical training and community exposure } \\
\hline Graduated from Pattimura University & 248 & 47 & 26 & 0.002 & $2.53(1.39-4.59)$ & & \\
\hline Multistages of learning using community exposure & 241 & 63 & 44 & 0.010 & $2.18(1.20-3.98)$ & & \\
\hline $\begin{array}{l}\text { Indicated positive impact of community exposure } \\
\text { to medical practice }\end{array}$ & 241 & 48 & 31 & 0.015 & $2.09(1.15-3.79)$ & 0.033 & $2.08(1.06-4.09)$ \\
\hline Multifocal community exposure & 241 & 82 & 66 & 0.024 & $2.26(1.10-4.67)$ & & \\
\hline Experienced rural exposure during medical training & 241 & 90 & 87 & 0.507 & $1.38(0.53-3.55)$ & & \\
\hline \multicolumn{8}{|l|}{ Employment factors } \\
\hline General practitioners & 248 & 94 & 82 & 0.031 & $3.13(1,06-9.22)$ & & \\
\hline Currently work in rural/remote Maluku & 248 & 90 & 54 & 0.000 & $7.72(3.17-18.8)$ & 0.000 & $8.23(3.27-20.8)$ \\
\hline Temporary employment status & 247 & 65 & 54 & 0.160 & $1.53(0.84-2.77)$ & & \\
\hline Monthly salary more than IDR 6 million & 248 & 44 & 32 & 0.090 & $1.66(0.92-3.00)$ & & \\
\hline Having no additional practice & 248 & 76 & 66 & 0.135 & $1.64(0.85-3.17)$ & & \\
\hline Monthly take home pay more than IDR 12 million & 248 & 21 & 36 & 0.034 & $0.48(0.24-0.93)$ & 0.005 & $0.30(0.13-0.70)$ \\
\hline
\end{tabular}

The bold emphasises the significance of the variables and their ORs

* The Chi-square statistic is significant at the 0.05 level

income and the four specialty areas align with international preferences among doctors and medical students [66-68]. We found that doctors currently practising RR were more likely to be a GP. Although there are currently few specialists in Maluku and there is a great need for more specialists, priority should be given to primary care, rural practice, rural generalist, and family medicine for these areas of practice are associated with improved recruitment and retention of $\mathrm{RR}$ medical human resources [27, 29, 30, 33, 34, 38, 69, 70].

We found that more doctors in Maluku Province received salaries up to IDR 6 million and take-home pay up to IDR 12 million. Moreover, monthly salary and take-home pay were relatively low regardless of the length of work (Fig. 3. IDR 5 million, equal to USD 350/ GBP 250 and IDR 34.5 million, equivalent to USD 2400 or GBP 1750, respectively). Salary more than IDR 6 million associated with more than 11-fold rates of current RR practice. This confirmed the importance of Indonesian government support through financial incentives included in the salary for doctors who practice rurally within Temporary Assignment and Nusantara Sehat schemes $[4,16,18]$. However, given the temporary status of many doctors, a higher salary appears unlikely to guarantee the sustainability of the RR medical workforce.

Meanwhile, preference for future RR practice in Maluku Province was associated with take-home pay less than IDR 12 million. Take-home pays more than IDR 12 million were related to the duration of practice of more than 10 years, additional practice and urban location. In addition, doctors who received a take-home pay of more than IDR 12 million were more likely of older age, permanent employees, and specialist medical doctors. Take-home pay includes medical service fees in Indonesian case-based groups (INA-CBGs) and or capitation within Indonesian National Health Insurance, also practice and other service fees. Those with permanent employment in health care centres or who have additional practice in primary clinics or private practices can benefit from capitation. Still, specialists get more 
payments from service fees in up to three hospitals and private practices [71]. As more primary clinics, private practices and hospitals were likely established in Maluku urban areas, and the UHC within Indonesian National Health Insurance in this province is still low [12], these benefits were less likely for doctors in RR settings. This means that RR practice in Maluku provides no promising rewards, highlighting the call from others internationally that meaningful reward for rural work is needed [72].

In addition, it is evident from this study that younger doctors (less than 33 years) were more likely to work rurally and intended to stay rurally, perhaps reflecting this generations' ethical stances around the world [73, 74]. They were more likely to take up and prefer rural practice; however, they received smaller take-home pay and mostly held temporary contracts. The rural work experience requirement and recommendation from the rural government for scholarship in specialist training from the Ministry of Health [75] means these rural posts are likely to temporarily attract younger doctors to rural service in Maluku. However, retaining doctors in rural and remote Maluku Province requires more than financial incentives. Evidence from elsewhere shows that educational [69, 76-81], multidimensional [82-86], and professional development strategies [87, 88] improves retention of doctors in RR areas. Multidimensional strategies [82-86] include the provision of infrastructure, facilities, and transportation-basic needs for health service improvement-the most challenging factors in the $\mathrm{RR}$ areas for medical doctors, which are less concerned in the remote and isolated islands and areas of Maluku Province [13-15]. Consequently, a collaboration between medical schools and local government is required to ensure relevant strategies are implemented to improve the recruitment and retention of doctors in RR areas.

This study shows that Pattimura University's graduate was significantly associated with all three outcome variables and independently associated with the intention to remain practice in Maluku. From this result, it can be said that Pattimura University has successfully produced doctors willing to serve in the RR areas of Maluku Province. This promising evidence supports the achievement of Pattimura University Medical School philosophy, akin to the vision of the Philippines medical school [89] and the vision for rural clinical schools in Australia [32, 40, 90].

Considerable evidence shows that a medical school intentionally established in a workforce shortage region pays much greater attention to the region's health status and concern. This is the case in both the developed [28, 91, 92] and developing world [56, 89, 93]. The medical school in The Philippines, Zamboanga [89], has a similarly rural, archipelago, and developing country context as Indonesia, so its findings are likely to be immediately relevant. This medical school showed that effective and sustainable medical education is possible in poor rural areas $[89,94]$. Compared to James Cook University which strongly favours applicants with rural backgrounds and requires a commitment to work rurally after graduation $[28,91,92]$, Pattimura University only stresses the philosophical value to practise rurally and offers rural exposure during medical training without any requirement for a rural background or commitment to work rurally.

From the successful experience of other universities [23, 32, 34, 56, 89, 93, 95], and based on this study's findings, Pattimura University could expand even further into the region's rural areas. Stressing the university's values by increasing the proportion of students with a rural background and ensuring rural exposure is offered at different year levels for a range of disciplines during the medical course will likely increase the number of graduates serving the RR areas of Maluku Province.

These data inform an argument for dedicated government support of recruiting people from areas of medical workforce shortage into medical school and support for students and graduate doctors through training and attractive opportunities to sustain their practices. These can subsequently retain the doctors in areas of workforce shortage.

The findings of this current study align with the WHO Guidelines on health workforce development, attraction, recruitment and retention in rural and remote areas [96] that recommends the combining or bundling up of strategies. These strategies include admitting students from a rural background, bringing education to the rural and remote areas in the province, implementing a comprehensive rural and remote curriculum in medicine and appropriate incentives for doctors working in rural and remote areas of Maluku. For greatest success, these strategies should be in collaboration between Pattimura Medical School, local authorities, community and civil society.

\section{Study limitation}

Pertaining to the sampling frame, we noted a difference in the number of doctors working in Maluku compare to the list provided from provincial and regents health offices and the medical school. There was no integrated database listing all doctors working in this province. The use of the Pattimura University alumni database to identify additional medical graduates augments the denominator for sampling but may potentially bias the participant sample.

Using a cross-sectional study, it is not possible to draw inferences of causality and outcomes of individual preferences and inclination to remain in rural practice, which 
can easily change. A longitudinal study is needed to track whether the participants are still in rural practice 5 to 10 years from now. Furthermore, due to the relatively large number of missing data despite the high response rate, this study may not have had the power to detect less strong associations between rural born and rural exposure in medical training and subsequent practice location.

This study only includes the graduates who currently work in Maluku province. Hence, there is a possibility of early-career bias to remain practising closer to where they trained. We realised that a further study is needed to track all Pattimura graduates workplace distribution across provinces in Indonesia.

The definition of rurality used in this study was the Indonesian national classification which may differ from other countries and make comparison challenging. Further studies on the RR workforce will benefit from applying the Degree of Urbanization, a United Nations (UN) recommendation on delineating cities, urban and rural areas for international statistical comparisons [97].

\section{Conclusion}

This study indicates that to build a sustainable RR workforce in Maluku Province, special attention should be given to recruitment and retention of doctors with a rural background, and ongoing support through attractive opportunities to sustain their practices; and that a regional medical school helps supply doctors to the RR areas in its region. Sustained collaboration between medical schools and local government implementing relevant strategies are needed to widen participation and improve the recruitment and retention of rural and remote doctors.

\section{Abbreviations}

RR: Rural and remote; OR: Odds ratio.

\section{Supplementary Information}

The online version contains supplementary material available at https://doi. org/10.1186/s12960-021-00667-z.

Additional file 1. Survey questionnaire.

\section{Acknowledgements}

The authors would like to acknowledge: The Dean of Pattimura University Medical School, Maluku Province government and health office, regents health offices in Maluku, for governance approval and facilitation in data collection. The Chair of Indonesian Medical Association in Maluku Province for general support and facilitation in data collection. Ms. Jeany Wattimena, an epidemiologist and statistician who provided statistical advice and consults regarding the study. Marty Firth, a statistic consultant from University of Western Australia Centre for Applied Statistic who provide consults and confirmation for the analysis made in this study.

\section{Authors' contributions}

FN led the design and conceptualisation of this work, drafted the protocol, developed the instrument, collected data, and conducted the analysis and data interpretation. SC, ST, RC, and DP guided the conceptualisation and design of the study and data analyses, and have revised all drafts of this manuscript for important intellectual content and clarity. All authors read and approve the final manuscript.

\section{Funding}

Funding for the design of the study and collection, analysis, and interpretation of data and in writing the manuscript provided by The University of Western Australia School of Allied Health, Division of Health Professions Education.

\section{Availability of data and materials}

The data sets used and/or analysed during the current study are available from the corresponding author on reasonable request.

\section{Declarations}

Ethics approval and consent to participate

Approval to conduct this study was provided by the University of Western Australia with Reference number RA/4/20/5065, and by Pattimura University, Indonesia with Reference number 008/FK-KOM. ETIKNVIII/2019, in accordance with its ethics review and approval procedures.

Consent to participate to this study was embedded in the online survey administered to the participants, in which participation in the survey means consent to participate.

\section{Consent for publication}

Not applicable.

\section{Competing interests}

The authors declare that they have no competing interests.

\section{Author details}

'Division of Health Professions Education, School of Allied Health, University of Western Australia, Perth, Australia. ${ }^{2}$ Medical Education Unit, Faculty of Medicine, Pattimura University, Ambon, Indonesia. ${ }^{3}$ Western Australian Centre for Rural Health, The University of Western Australia, Perth, Australia. ${ }^{4}$ School of Allied Health, University of Western Australia, Perth, Australia. ${ }^{5}$ The Rural Clinical School of WA, School of Medicine, The University of Western Australia, Perth, Australia. ${ }^{6}$ Health Professions Education Building, The University of Western Australia, Crawley Avenue (off Mounts Bay Road-next to CAR PARK 25), Nedlands, WA 6009, Australia.

Received: 26 April 2021 Accepted: 28 September 2021

Published online: 09 October 2021

\section{References}

1. Strasser R, Andre-Jacques N. Context counts: training health workers in and for rural remote areas. Bull World Health Organ. 2010;88:777-82.

2. Versteeg M, du Toit L, Couper I. Building consensus on key priorities for rural health care in South Africa using the Delphi technique. Glob Health Action. 2013;6:119-26. https://doi.org/10.3402/gha.v6i0.19522.

3. Thompson SC, Cheetham S, Baxi S. The enablers, barriers and preferences of accessing radiation therapy facilities in the rural developed world - a systematic review. BMC Cancer. 2017;17:794.

4. Efendi F. Health worker recruitment and deployment in remote areas of Indonesia. Rural Remote Health. 2012;12(2):[about 6 p].

5. World Health Organization. Country cooperation strategy at a glance. Indonesia. 2018. https://apps.who.int/iris/rest/bitstreams/609150/retri eve.

6. World Health Organization. The 2018 update, Global Health Workforce statistics. Geneva: World Health Organization; 2018.

7. Head of the Central Statistic Agency. Regulation of The Head of The Central Statistic Agency Number 37 of The Year 2010 concerning Classification of Urban and Rural in Indonesia. In: Central Statistic Agency, editor. 
Book 3 Bali, Nusa Tenggara, Kalimantan, Sulawesi, Maluku, and Papua. Jakarta; 2010.

8. The Ministry of Health of the Republic of Indonesia. Data and information: Indonesia health profile 2017. Jakarta: The Ministry of Health of the Republic of Indonesia; 2017.

9. World Health Organization. Maternal mortality. 2019. https://www.who. int/news-room/fact-sheets/detail/maternal-mortality. Accessed 12 June 2021.

10. United Nations Children's Fund. Child survival and the SDGs. 2020. https://data.unicef.org/topic/child-survival/child-survival-sdgs/. Accessed 12 June 2021.

11. The Ministry of Finance of the Republic of Indonesia. APBN 2018. 2018. https://www.kemenkeu.go.id/apbn2018. Accessed 23 Sept 2018.

12. Herawati, Franzone R, Chrisnahutama A. Universal health coverage: tracking Indonesia's progress. Jakarta: Perkumpulan PRAKARSA; 2020.

13. President of Republic of Indonesia. Presidential regulation number 131 of the year 2015 regarding the determination of underdeveloped areas for the year 2015-2019. Jakarta: Ministry of State Secretariat; 2015.

14. President of Republic of Indonesia. Presidential decree number 6 of the year 2017 concerning the determination of the outermost small islands. Jakarta: The Secreatariat of Cabinet of The Republic of Indonesia; 2017.

15. Minister of Health of the Republic of Indonesia. Regulation of the Minister of Health of the Republic of Indonesia number 6 of the year 2013 concerning the criteria for remote, very remote, and unattractive health care facilities. Jakarta: Ministry of Health of The Republic of Indonesia; 2013.

16. Chomitz KM, Setiadi G, Azwar A, Ismail N, Widiyarti A. What do doctors want? developing incentives for doctors to serve in Indonesia's rural and remote areas. Washington DC: World Bank Development Research Group; 1998.

17. Laksono AD, Ridlo IA, Ernawaty E. Distribution analysis of doctors in Indonesia. Indones J Health Adm. 2020:8(1):11. https://doi.org/10.20473/ jaki.v8i1.2020.29-39.

18. Minister of Health of the Republic of Indonesia. Regulation of the Minister of Health of the Republic of Indonesia number 33 of the year 2018 concerning special assignment for health workers for Nusantara Sehat Program. Jakarta: Ministry of Health of the Republic of Indonesia; 2018.

19. Narpiti D, Hasabasri M, Meliala A. Analysis of factors influenced retention of doctors and dentists in underserved areas. Yogyakarta: Universitas Gajah Mada; 2015.

20. Indonesian Centre Bureau of Statistic. Indonesian population profile based on SUPAS 2015. Jakarta: Indonesian Centre Bureau of Statistic; 2015.

21. Strasser R, Neusy AJ. Context counts: training health workers in and for rural and remote areas. Bull World Health Organ. 2010;88(10):777-82.

22. Wakerman J. Defining remote health. Aust J Rural Health. 2004;12(5):2104. https://doi.org/10.1111/j.1440-1854.2004.00607.x.

23. Strasser R. Social accountability and the supply of physicians for remote rural Canada. CMAJ. 2015;187(11):791-2.

24. Noya F, Freeman K, Carr S, Thompson S, Clifford R, Playford D. Approaches to facilitate improved recruitment, development, and retention of the rural and remote medical workforce: a scoping review protocol. Int J Health Policy Manag. 2021;10(1):22-8. https://doi.org/10.34172/ijhpm. 2020.27.

25. McGrail MR, Russell DJ, Campbell DG. Vocational training of general practitioners in rural locations is critical for the Australian rural medical workforce. Med J Aust. 2016;205(5):216-21.

26. Beauchamp J, Belanger M, Schofield A, Bordage R, Donovan D, Landry $M$. Recruiting doctors from and for underserved groups: Does new brunswick's initiative to recruit doctors for its linguistic minority help rural communities? Can J Public Health. 2013;104(6 SUPPL.1):S44-8.

27. Matsumoto M, Inoue K, Kajii E. Policy implications of a financial incentive programme to retain a physician workforce in underserved Japanese rural areas. Soc Sci Med. 2010;71(4):667-71.

28. Ray RA, Woolley T, Gupta TS. James Cook University's rurally orientated medical school selection process: quality graduates and positive workforce outcomes. Rural Remote Health. 2015;15(4):3424.

29. Rabinowitz HK, Diamond JJ, Markham FW, Santana AJ. The relationship between entering medical students' backgrounds and career plans and their rural practice outcomes three decades later. Acad Med. 2012;87(4):493-7.
30. Hogenbirk JC, MCGrail MR, Strasser R, Lacarte SA, Kevat A, Lewenberg M. Urban washout: How strong is the rural-background effect? Aust J Rural Health. 2015;23(3):161-8. https://doi.org/10.1111/ajr.12183.

31. Runge CE, Mackenzie A, Loos C, et al. Characteristics of Queensland physicians and the influence of rural exposure on practice location. Intern Med J. 2016;46(8):981-5.

32. Playford DE, Evans SF, Atkinson DN, Auret KA, Riley GJ. Impact of the Rural Clinical School of Western Australia on work location of medical graduates. Med J Aust. 2014;200(2):104-7. https://doi.org/10.5694/mja13. 11082.

33. Crump WJ, Fricker RS, Ziegler CH, Wiegman DL. Increasing the Rural Physician Workforce: a potential role for small rural medical school campuses. J Rural Health. 2016;32(3):254-9. https://doi.org/10.1111/jrh.12156.

34. Playford D, Ngo H, Gupta S, Puddey IB. Opting for rural practice: the influence of medical student origin, intention and immersion experience. Med J Aust. 2017;207(4):154-8. https://doi.org/10.5694/mja16.01322.

35. Kwan MMS, Kondalsamy-Chennakesavan S, Geetha R, Toombs MR, Nicholson GC. The rural pipeline to longer-term rural practice: general practitioners and specialists. PLoS ONE. 2017;12(7):e0180394.

36. Fuglestad A, Prunuske J, Regal R, Hunter C, Boulger J, Prunuske A. Rural family medicine outcomes at the University of Minnesota Medical School Duluth. Fam Med. 2017:49(5):388-93.

37. McGrail MR, O'Sullivan BG, Russell DJ. Rural training pathways: the return rate of doctors to work in the same region as their basic medical training. Hum Resour Health [Electronic Resource]. 2018;16(1):56.

38. Campbell DG, McGrail MR, O'Sullivan B, Russell DJ. Outcomes of a 1-year longitudinal integrated medical clerkship in small rural Victorian communities. Rural Remote Health. 2019;19(2):4987. https://doi.org/10.22605/ RRH4987.

39. Playford DE, Mercer A, Carr SE, Puddey IB. Likelihood of rural practice in medical school entrants with prior tertiary experience. Med Teach. 2019;41(7):765-72. https://doi.org/10.1080/0142159x.2019.1570099.

40. McGirr J, Seal A, Barnard A, et al. The Australian Rural Clinical School (RCS) program supports rural medical workforce: evidence from a cross-sectional study of 12 RCSs. Rural Remote Health. 2019;19(1):4971. https://doi. org/10.22605/rrh4971.

41. Woolley T, Sen Gupta T, Murray R, Hays R. Predictors of rural practice location for James Cook University MBBS graduates at postgraduate year 5. Aust J Rural Health. 2014;22(4):165-71. https://doi.org/10.1111/ajr.12106.

42. Matthews C, Bagg W, Yielder J, Mogol V, Poole P. Does Pukawakawa (the regional-rural programme at the University of Auckland) influence workforce choice? N Z Med J. 2015;128(1409):35-43.

43. Petrany SM, Gress T, Poole D. A free clinic continuity experience during residency is associated with practice in underserved areas. J Grad Med Educ. 2017;9(5):595-9.

44. O'Sullivan B, McGrail M, Russell D, et al. Duration and setting of rural immersion during the medical degree relates to rural work outcomes. Med Educ. 2018;52(8):803-15.

45. Playford DE, Nicholson A, Riley GJ, Puddey IB. Longitudinal rural clerkships: increased likelihood of more remote rural medical practice following graduation. BMC Med Educ. 2015;15:55.

46. Shires L, Allen P, Cheek C, Wilson D. Regional universities and rural clinical schools contribute to rural medical workforce, a cohort study of 2002-2013 graduates. Rural Remote Health. 2015;15(3):3219.

47. Woolley T, Gupta TS, Murray R. James Cook University's decentralised medical training model: an important part of the rural workforce pipeline in northern Australia. Rural Remote Health. 2016;16(1):3611-21.

48. Moore M, Burgis-Kasthala S, Barnard A, Hall S, Marks S. Rural clinical school students do come back: but it may take time. Aust J Gen Pract. 2018;47(11):812-4. https://doi.org/10.31128/ajgp-02-18-4505.

49. Myhre DL, Bajaj S, Woloschuk W. Practice locations of longitudinal integrated clerkship graduates: a matched-cohort study. Can J Rural Med. 2016;21(1):13-6.

50. Berita Maluku Online. Far Far: the population of Maluku is in accordance with WHO standards. Berita Maluku Online. 2015.

51. Minister of Health of the Republic of Indonesia. Regulation of the Minister of Health of the Republic of Indonesia number 2052 of the year 2011 concerning license of practice and implementation of medical practices. Jakarta: Indonesia MoHotRo; 2011. 
52. Jamieson JL, Kernahan J, Calam B, Sivertz KS. One program, multiple training sites: does site of family medicine training influence professional practice location? Rural Remote Health. 2014;14(1):1-12.

53. Putri LP, Russell DJ, O'Sullivan BG, Kippen R. Factors associated with working in remote Indonesia: a national cross-sectional study of early-career doctors. Front Med (Lausanne). 2021;8:594695. https://doi.org/10.3389/ fmed.2021.594695.

54. Handoyo NE, Rahayu GR, Claramita M, Ash J, Schuwirth LW. Personal resilience and rural doctors retention: a study in Indonesia. Rural Remote Health. 2020;20:6097. https://doi.org/10.22605/RRH6097.

55. Shires $L$, Allen $P$, Cheek $C$, Deb W. Regional universities and rural clinical schools contribute to rural medical workforce, a cohort study of 2002 to 2013 graduates. Rural Remote Health. 2015;15(3):3219.

56. Mian O, Hogenbirk JC, Warry W, Strasser RP. How underserviced rural communities approach physician recruitment: changes following the opening of a socially accountable medical school in northern Ontario. Can J Rural Med. 2017;22(4):139-47.

57. Gupta TS, Woolley T, Murray R, Hays R, McCloskey T. Positive impacts on rural and regional workforce from the first seven cohorts of James Cook University medical graduates. Rural Remote Health. 2014;14:2657.

58. Easterbrook M, Godwin M, Wilson R, et al. Rural background and clinical rural rotations during medical training: effect on practice location. CMAJ Can Med Assoc J. 1999;160(8):1159-63.

59. Playford D, Ngo H, Puddey I. Intention mutability and translation of rural intention into actual rural medical practice. Med Educ. 2021;55(4):496504. https://doi.org/10.1111/medu.14404.

60. The Health Office of Maluku Province. Maluku health profile 2014 Ambon: The Health Office of Maluku Province; 2014.

61. Dowell J, Norbury M, Steven K, Guthrie B. Widening access to medicine may improve general practitioner recruitment in deprived and rural communities: survey of GP origins and current place of work. BMC Med Educ. 2015;15:165. https://doi.org/10.1186/s12909-015-0445-8.

62. Puddey IB, Mercer A, Playford DE, Riley GJ. Medical student selection criteria and socio-demographic factors as predictors of ultimately working rurally after graduation. BMC Med Educ. 2015;15:74.

63. Puddey IB, Playford DE, Mercer A. Impact of medical student origins on the likelihood of ultimately practicing in areas of low vs high socioeconomic status. BMC Med Educ. 2017;17(1):1.

64. Adendorff J, Sutherland D, Nielsen N. The implications of an affirmative action student selection process for the rural medical workforce. In: 6th National Rural Health conference. Canberra, Australian Capital Territory, Australia. 2001.

65. Brown T, Liu JX, Scheffler RM. Does the under- or overrepresentation of minority physicians across geographical areas affect the location decisions of minority physicians? Health Serv Res. 2009;44(4):1290-308. https://doi.org/10.1111/j.1475-6773.2009.00978.x.

66. Grasreiner D, Dahmen U, Settmacher U. Specialty preferences and influencing factors: a repeated cross-sectional survey of first- to sixth-year medical students in Jena, Germany. BMC Med Educ. 2018;18(1):103. https://doi.org/10.1186/s12909-018-1200-8.

67. Buddeberg-Fischer B, Klaghofer R, Abel T, Buddeberg C. Swiss residents' speciality choices - impact of gender, personality traits, career motivation and life goals. BMC Health Serv Res. 2006;6(1):137. https://doi.org/10. 1186/1472-6963-6-137.

68. Kaliyadan F, Amin T, Qureshi H, AI WF. Specialty preferences of 1st year medical students in a Saudi Medical School_factors affecting these choices and the influence of gender. Avicenna J Med. 2015;5(4):134-9. https://doi.org/10.4103/2231-0770.165120.

69. MacDowell M, Glasser M, Hunsaker M. A decade of rural physician workforce outcomes for the Rockford Rural Medical Education (RMED) Program, University of Illinois. Acad Med. 2013;88(12):1941-7. https://doi. org/10.1097/acm.0000000000000031.

70. Woolley T, Sen Gupta T, Bellei M. Predictors of remote practice location in the first seven cohorts of James Cook University MBBS graduates. Rural Remote Health. 2017;17(1):3992.

71. Thabrany H, Setiawan E, Puteri GC, et al. Evaluation study of the implementation of graded referral system in the era of JKN-KIS (Indonesian National Health Insurance). Research summary of JKN-KIS. 2017;3(October).
72. Henderson LN, Tulloch J. Incentives for retaining and motivating health workers in Pacific and Asian countries. Hum Resour Health. 2008;6(1):18. https://doi.org/10.1186/1478-4491-6-18.

73. Cuesta-Briand B, Coleman M, Ledingham R, et al. Understanding the factors influencing junior doctors' career decision-making to address rural workforce issues: testing a conceptual framework. Int J Environ Res Public Health. 2020;17(537):1-12. https://doi.org/10.3390/ijerph17020537.

74. Matsumoto M, Inoue K, Kashima S, Takeuchi K. Characteristics of physicians, their migration patterns and distance: a longitudinal study in Hiroshima, Japan. Rural Remote Health. 2012;12(2):2027.

75. Minister of Health of the Republic of Indonesia. Regulation of the Minister of Health of The Republic of Indonesia number 53 of the Year 2013 concerning specialist educational assistance program for medical doctors and dentists. Jakarta: Ministry of Health of The Republic of Indonesia; 2013.

76. Boonluksiri P, Tumviriyakul H, Arora R, Techakehakij W, Chamnan P, Umthong N. Community-based learning enhances doctor retention. Educ Health Change Learn Pract. 2018;31(2):114-8. https://doi.org/10. 4103/efh.EfH_153_17.

77. Morken C, Bruksch-Meck K, Crouse B, Traxler K. Factors influencing rural physician retention following completion of a rural training track family medicine residency program. WMJ. 2018;117(5):208-10.

78. Glasser M, MacDowell M, Hunsaker M, et al. Factors and outcomes in primary care physician retention in rural areas. S Afr Fam Pract. 2010;52(4):336-40.

79. Orda U, Orda S, Gupta TS, Knight S. Building a sustainable workforce in a rural and remote health service: a comprehensive and innovative Rural Generalist training approach. Aust J Rural Health. 2017;25(2):116-9.

80. Robinson M, Slaney GM. Choice or chance! The influence of decentralised training on GP retention in the Bogong region of Victoria and New South Wales. Rural Remote Health. 2013;13(1):1-12.

81. Straume K, Sondena MS, Prydz P. Postgraduate training at the ends of the earth - a way to retain physicians? Rural Remote Health. 2010;10(2):1356.

82. Straume K, Shaw DM. Effective physician retention strategies in Norway's northernmost county. Bull World Health Organ. 2010;88(5):390-4.

83. Pena S, Ramirez J, Becerra C, Carabantes J, Arteaga O. The Chilean rural practitioner programme: a multidimensional strategy to attract and retain doctors in rural areas. Bull World Health Organ. 2010;88(5):371-8 (French).

84. Kehlet K, Aaraas IJ. "The Senja Doctor": developing joint GP services among rural communities in Northern Norway. Rural Remote Health. 2015;15(3):1-6.

85. Arora R, Chamnan P, Nitiapinyasakul A, Lertsukprasert S. Retention of doctors in rural health services in Thailand: impact of a national collaborative approach. Rural Remote Health. 2017;17(3):4344.

86. MacVicar R, Clarke G, Hogg DR. Scotland's GP Rural Fellowship: an initiative that has impacted on rural recruitment and retention. Rural Remote Health. 2016;16(1):3550.

87. Gorsche RG, WoloschukW. Rural physicians'skills enrichment program: a cohort control study of retention in Alberta. Aust J Rural Health. 2012;20(5):254-8. https://doi.org/10.1111/j.1440-1584.2012.01298.x.

88. Martin P, Gupta TS, Bond D, Douyere J, Mills K. Rural competencies in emerging medical practitioners: beyond clinical skills. Aust J Rural Health. 2019;27(5):427-32.

89. Cristobal F, Worley P. Can medical education in poor rural areas be cost-effective and sustainable: the case of the Ateneo de Zamboanga University School of Medicine. Rural Remote Health. 2012;12(1):1-7.

90. Greenhill JA, Walker J, Playford D. Outcomes of Australian rural clinical schools: a decade of success building the rural medical workforce through the education and training continuum. Rural Remote Health. 2015;15(3):2991.

91. Chopra A. JCU medical graduates' preparedness for remote practice. Rural Remote Health. 2015;15(4):3202.

92. Sen Gupta T, Murray R, Hays R, Woolley T. James Cook University MBBS graduate intentions and intern destinations: a comparative study with other Queensland and Australian medical schools. Rural Remote Health. 2013;13(2):2313.

93. Hogenbirk JC, French MG, Timony PE, Strasser RP, Hunt D, Pong RW. Outcomes of the Northern Ontario School of Medicine's distributed medical education programmes: protocol for a longitudinal comparative multicohort study. BMJ Open. 2015;5(7):e008246. 
94. Halili S Jr, Cristobal F, Woolley T, Ross SJ, Reeve C, Neusy AJ. Addressing health workforce inequities in the Mindanao regions of the Philippines: tracer study of graduates from a socially-accountable, communityengaged medical school and graduates from a conventional medical school. Med Teach. 2017;39(8):859-65.

95. Playford D, Puddey IB. Interest in rural clinical school is not enough: participation is necessary to predict an ultimate rural practice location. Aust J Rural Health. 2017;25(4):210-8. https://doi.org/10.1111/ajr.12324.

96. World Health Organization. WHO guideline on health workforce development, attraction, recruitment and retention in rural and remote areas. Geneva: World Health Organization; 2021.

97. The European Union, The Food and Agriculture Organization of the United Nations (FAO), The International Labour Office (ILO), The
Organization for Economic Co-operation and Development (OECD), United Nations Human Settlements Programme (UN-Habitat), The World Bank. A recommendation on the method to delineate cities, urban and rural areas for international statistical comparisons. New York: United Nation Statistical Commission; 2020.

\section{Publisher's Note}

Springer Nature remains neutral with regard to jurisdictional claims in published maps and institutional affiliations.
Ready to submit your research? Choose BMC and benefit from:

- fast, convenient online submission

- thorough peer review by experienced researchers in your field

- rapid publication on acceptance

- support for research data, including large and complex data types

- gold Open Access which fosters wider collaboration and increased citations

- maximum visibility for your research: over $100 \mathrm{M}$ website views per year

At BMC, research is always in progress.

Learn more biomedcentral.com/submissions 